\title{
Gender differences in hyposmic men and women
}

\section{Abstract}

Background: Differences in smell function between men and women have been studied by several investigators with variable results. We were interested in determining if differences in olfactory function might occur between men and women with loss of smell (hyposmia). To do this we evaluated their olfactory function before and after oral theophylline treatment.

Methods: Three hundred twelve patients with hyposmia, 178women and 134men, with chronic smell dysfunction of several etiologies were studied in an open-label controlled clinical trial before and after daily treatment with oral theophylline with doses of 200$600 \mathrm{mg}$ for periods of $2-10$ months. Smell function was measured both subjectively and by olfactometry before and at termination of each treatment period as was serum theophylline.

Results: Before oral theophylline treatment there were no significant gender differences in olfactory function between hyposmic men and women. However, after theophylline treatment, which improved smell function in both men and women subjectively, improvement was greater in women than in men but clinically apparent by olfactometry only after a theophylline dose of $600 \mathrm{mg}$ at which time differences were statistically significant.

Conclusion: These results indicate relative increased olfactory sensitivity in hyposmic women compared to hyposmic men after treatment with oral theophylline which improved smell function in both groups. Although mechanism(s) are not well defined these results could relate to a differential effect of theophylline on smell function relative to decreased metabolic clearance of theophylline in women than in men.

Keywords: gender, hyposmia, theophylline, phosphodiesterase inhibitors, drug responses, smell function, olfactory measurements, smell loss, smell acuity, metabolic clearance rate
Volume 10 Issue 4 - 2018

\author{
Robert I Henkin \\ Director, Center for Molecular Nutrition and Sensory \\ Disorders, USA
}

Correspondence: Robert I Henkin, Director, Center for Molecular Nutrition and Sensory Disorders, 5125 MacArthur Blvd. NW, \#20,Washington, DC 20016, Tel (202) 364-4I80, Emaildoc@tasteandsmell.com

Received: March 30, 2018| Published: August 10, 2018
Abbreviations: fMRI, functional magnetic resonance imaging; DT, detection thresholds; RT, recognition thresholds; ME, magnitude estimation

\section{Introduction}

Smell function has been reported by some investigators to differ in men and women with women exhibiting greater olfactory sensitivity than men. ${ }^{1-5}$ However, other investigators were unable to document these differences. ${ }^{6-11}$ These differences emphasize the complex problems of specifying differences in olfactory sensitivity between men and women.

We have studied olfaction in patients with smell loss (hyposmia) for many years. ${ }^{12-14}$ Some of these studies involved treatment with the oral phosphodiesterase inhibitor theophylline which improved smell function in over $50 \%$ of these patients. ${ }^{12,13}$ This improvement was demonstrated by both psychophysical techniques (olfactometry) ${ }^{12-14}$ and functional magnetic resonance imaging (fMRI) of brain..$^{15}$ Initial analysis of these olfactometry data did not demonstrate any obvious gender differences in smell function either before or after treatment. ${ }^{12-14}$ However, more detailed analysis of these data suggested that women improved their smell function with oral theophylline treatment more than did men but mainly at higher doses of the drug. Because of these post hoc analyses we re-evaluated these data to determine if differences in smell function between hyposmic men and women occurred after theophylline treatment and attempted to understand how these differences occurred.

\section{Methods}

\section{Patients}

Three hundred and twelve patients with chronic hyposmia were studied at The Taste and Smell Clinic in Washington, DC. These included 178women, aged 18-85y (55 $\pm 2 \mathrm{y}, \mathrm{Mean} \pm \mathrm{SEM})$ and $134 \mathrm{men}$, aged 23-86y (54 $\pm 3 y)$. All patients presented themselves to The Clinic for evaluation and treatment of loss of smell. Patients complained of loss of smell with loss present for a mean period of 3.5years prior to their visit to The Clinic. ${ }^{13,14}$ Patients were treated with oral theophylline at 200,400 and $600 \mathrm{mg}$ of the drug in two divided doses taken mid breakfast and lunch. Treatment was given for periods of two to 10 months with patients returning for re-evaluation at the end of each period.

All patients began theophylline treatment on $200 \mathrm{mg}$ in two divided doses for 2-6months. If patients improved their smell loss subjectively $(\geq 5 \%)$ they were continued on that dose (see reference 12 for details). If they did not improve their dose of theophylline was increased to $400 \mathrm{mg}$ in two divided doses for 2-6months. Upon their return to The Clinic if their subjective responses increased $(\geq 5 \%)$ they were continued on that dose. If they did not improve their dose of theophylline was increased to $600 \mathrm{mg}$ in two divided doses and reevaluated at 2-6months. The study was terminated with the patients at this dose of theophylline.

Patients were classified into six etiological categories: ${ }^{13,14}$ allergic rhinitis [ ${ }^{1697}$ patients], congenital hyposmia [ ${ }^{17} 23$ patients], head injury [ ${ }^{18} 47$ patients], idiopathic hyposmia [12,1428patients], post-influenzalike hyposmia [ ${ }^{19} 97$ patients] and other pathologies [12,1420patients].

\section{Procedures}

Smell function was evaluated by both subjective measurements and by olfactometry.

Subjective measurements: obtained after treatment by questionnaire. Responses were graded on a scale from 0100 with 0 reflecting no change to 100 reflecting return to normal function and values between 0-100 reflecting return of less than 100 but greater 
than $0.13,14$ Improvement was considered present if patients reported $\geq 5 \%$ improvement in smell of all odors. ${ }^{13,14}$

Olfactometry: obtained both before and after treatment. These included measurements of detection thresholds (DT), recognition thresholds (RT), magnitude estimation of odor intensity (ME) and hedonic responses $(\mathrm{H})$ reflecting odor pleasantness, unpleasantness or neutrality [based upon scales of $0-100$ with $+1-+100$ reflecting pleasantness, $-1-100$ reflecting unpleasantness and 0 reflecting neutrality] to the four odors used [pyridine (pungent odor), nitrobenzene (bitter almond odor), thiophene (petroleum odor) and amyl acetate (banana oil odor); ${ }^{13,14}$ many of these techniques were confirmed in a prior controlled double-blind clinical trial. ${ }^{20}$

Smell function was measured in the morning three to four hours after the first theophylline dose. Measurements were made by technicians who were masked about the specific patient treatment but were aware that patients were in a treatment process to evaluate their smell loss. Improvement in smell function was defined by decreased DTs and/or RTs (increased sensitivity), increased MEs (increased sensitivity) and changes in Hs consistent with increased pleasantness (for nitrobenzene and amyl acetate) or increased unpleasantness (for pyridine and thiophene). While all experimenters were aware of the overall plan of this study, all were blinded with respect to the clinical status or treatment dose of each subject at each patient visit.

Serum for theophylline measurements were obtained three to four hours after the first drug dose at the end of each treatment period. Blood was obtained by venipuncture, placed into plastic tubes on ice, centrifuged in a refrigerated centrifuge at $3000 \mathrm{xg}$ for $10-20 \mathrm{~min}$, the serum analyzed by fluorescence polarization immunoassay ${ }^{21}$ within $12 \mathrm{hr}$ of collection. All measurements were coded, performed in a blinded manner and results assembled only after all sensory data were calculated. Body weight was determined at each clinic visit on a calibrated clinical scale immediately prior to smell function measurements.

\section{Statistics}

Subjective smell responses, olfactometry, etiological categories of smell loss, body mass, serum protein and hormonal status (for women) and serum theophylline levels in men and women at each theophylline dose were assembled after all data were collected. Mean \pm SEM of all measurements at each theophylline dose level by gender and by clinical etiology of hyposmia were calculated and results between each treatment group compared. Differences were measured by parametric (Student $t$ tests and $\mathrm{X}^{2}$ ) and non-parametric (sign test) tests and considered significant if $p<0.05$. ANOVA was performed with gender, body mass and theophylline dose as variables with differences of $\mathrm{p}<0.05$ considered significant.

All studies were performed at The Taste and Smell Clinic in Washington, DC between February 2001 and November 2007 and constitute studies on consecutive hyposmic patients. Studies were completed in 2009. Studies were approved by the Institutional Review Board of the Georgetown University Medical Center, Washington, DC. Each patient agreed to participate in the study by giving written informed consent.

\section{Results}

Overall subjective improvement in smell function on $200-400 \mathrm{mg}$ of oral theophylline was not associated with any differential response between men and women. However, after $600 \mathrm{mg}$ of oral theophylline treatment, subjective improvement in smell function was significantly greater in women than in men with an increased sensitivity in women of $36 \%$ (Table 1). For each etiology of smell loss serum theophylline was higher in women than in men and statistically significant for all patients and for patients with allergic rhinitis and other pathologies. As noted before, overall women reported a significantly greater subjective improvement in smell function than did men. Relative subjective changes in smell function demonstrate increased smell function among women in four of six etiological categories-allergic rhinitis, congenital smell loss and head injury but not in patients with idiopathic hyposmia or post-influenza-like hyposmia. Significant differences between men and women were demonstrated only for patients with other pathologies. Increased serum theophylline was demonstrated in women over men for all patients and significant differences noted in all patients and in patients with other pathologies. No subjective changes were noted after $200-400 \mathrm{mg}$ of oral theophylline treatment and there were no differences in responsiveness between men and women (data not shown).

Table I Subjective responses in olfactory function to treatment with oral theophylline, $600 \mathrm{mg}$ daily, between hyposmic men and women and by hyposmia etiology

\begin{tabular}{|c|c|c|c|}
\hline Patient diagnosis & & $\begin{array}{l}\text { Subjective } \\
\text { improvement } \\
{[\%]}\end{array}$ & $\begin{array}{l}\text { Serum } \\
\text { theophylline } \\
{[\mathrm{mg} / \mathrm{L}]}\end{array}$ \\
\hline \multirow[t]{2}{*}{ All Patients } & Men (I34) & $15 \pm 2.0^{*}$ & $8.5 \pm 0.4$ \\
\hline & Women (I78) & $22 \pm 1.8^{d}$ & $11.6 \pm 0.7^{\mathrm{a}}$ \\
\hline \multirow[t]{2}{*}{ Allergic Rhinitis } & Men (52) & $19 \pm 4$ & $7.7 \pm 0.5$ \\
\hline & Women (45) & $30 \pm 6$ & $12.5 \pm 1 . \mathrm{I}^{\mathrm{a}}$ \\
\hline \multirow[t]{2}{*}{ Congenital Hyposmia } & Men (7) & $2 \pm 1$ & $8.4 \pm 1.4$ \\
\hline & Woman (16) & $16 \pm 6^{e}$ & $9.8 \pm 2.3$ \\
\hline \multirow[t]{2}{*}{ Head Injury } & Men (I8) & $17 \pm 7$ & $7.0 \pm 1.1$ \\
\hline & Women (25) & $19 \pm 6$ & $10.1 \pm 1.2$ \\
\hline \multirow[t]{2}{*}{ Idiopathic Hyposmia } & Men (I8) & $14 \pm 7$ & $10.0 \pm 1.2$ \\
\hline & Women (10) & $13 \pm 6$ & $|3| \pm 2.6$. \\
\hline \multirow[t]{2}{*}{$\begin{array}{l}\text { Post Influenza-Like } \\
\text { Hyposmia }\end{array}$} & Men (36) & $38 \pm 7$ & $7.8 \pm 0.8$ \\
\hline & Women (6I) & $30 \pm 5$ & $8.7 \pm 0.7$ \\
\hline \multirow[t]{2}{*}{ Other Pathology } & Men (3) & $12 \pm 2$ & $7.9 \pm 1.1$ \\
\hline & Women (I7) & $26 \pm 3^{a}$ & $12.9 \pm 1.5^{d}$ \\
\hline
\end{tabular}

\section{*Mean \pm SEM}

()Number of Patients

With respect to men

${ }^{\mathrm{a}} \mathrm{p}<0.00$ I

${ }^{\mathrm{d}} \mathrm{P}<0.025$

${ }^{\mathrm{e}} \mathrm{p}<0.05$

Olfactometry results in hyposmic men and women before and after oral theophylline treatment are shown in Table 2. Before treatment there were no significant gender differences in any smell parameter (either DT, RT, ME or H); however, DTs for each odor were increased (less sensitive) in women compared to men and RTs for each odor was either similar (for pyridine or amyl acetate), increased (less sensitive) (for nitrobenzene) or slightly decreased (more sensitive) (for thiophene) in women compared to men. 
Table 2 Differences in olfactometry and in serum theophylline between hyposmic men and women

\begin{tabular}{|c|c|c|c|c|c|c|c|c|c|}
\hline & & \multicolumn{8}{|c|}{ Theophylline dosage (mg) } \\
\hline & & \multicolumn{4}{|c|}{ Pre treatment } & \multicolumn{4}{|l|}{200} \\
\hline \multirow[t]{2}{*}{ Serum Theophylline } & Men & 0.0 & & & & $3.5 \pm 0.2 \dagger$ & & & \\
\hline & Women & 0.0 & & & & $4.4 \pm 0.3^{\mathrm{e}}$ & & & \\
\hline $\begin{array}{l}\text { Olfactometry (see ref } \\
22 \text { ) }\end{array}$ & & PYRD & $\mathrm{NO}_{2} \mathbf{B}$ & THIO & AA & PYRD & $\mathrm{NO}_{2} \mathrm{~B}$ & THIO & AA \\
\hline Detection & Men & $8.7 \pm 0.3 *$ & $9.5 \pm 0.3$ & $9.2 \pm 0.4$ & $9.6 \pm 0.3$ & $8.4 \pm 0.4$ & $9.3 \pm 0.5$ & $9.2 \pm 0.5$ & $9.5 \pm 0.5$ \\
\hline Threshold (in BU) & Woman & $9.1 \pm 0.2$ & $10.0 \pm 0.3$ & $9.4 \pm 0.3$ & $10.1 \pm 0.3$ & $8.7 \pm 0.3$ & $9.0 \pm 0.4$ & $8.9 \pm 0.4$ & $9.5 \pm 0.4$ \\
\hline Recognition & Men & $10.7 \pm 0.2$ & $10.6 \pm 0.3$ & $11.0 \pm 0.2$ & $|I| \pm 0.2$. & $9.8 \pm 0.4^{\mathrm{el}}$ & $10.3 \pm 0.3$ & $10.6 \pm 0.4$ & $10.9 \pm 0.2$ \\
\hline Threshold (in BU) & Women & $10.7 \pm 0.3$ & $11.2 \pm 0.2$ & $10.8 \pm 0.3$ & $I I . I \pm 0.2$ & $10.0 \pm 0.3$ & $10.6 \pm 0.3$ & $10.2 \pm 0.4$ & $10.5 \pm 0.3$ \\
\hline Magnitude & Men & $17.0 \pm 2.6$ & $9.5 \pm 2.1$ & $9.2 \pm 2.2$ & $5.9 \pm 1.6$ & $22.4 \pm 4.0$ & $11.3 \pm 3.0$ & $11.1 \pm 3.2$ & $8.1 \pm 2.5$ \\
\hline Estimation (\%) & Women & $18.2 \pm 2.9$ & $7.1 \pm 1.8$ & $11.5 \pm 2.5$ & $5.8 \pm 1.4$ & $19.8 \pm 3.4$ & $8.3 \pm 2.1$ & $12.3 \pm 2.9$ & $10.4 \pm 2.5$ \\
\hline Hedonic & Men & $-13.6 \pm 2.4$ & $2.8 \pm 1.8$ & $-5.8 \pm 2.1$ & $3.1 \pm 1.3$ & $-15.6 \pm 4.4$ & $4.6 \pm 3.0$ & $-7.0 \pm 3.3$ & $0.8 \pm 1.6$ \\
\hline \multirow[t]{3}{*}{ Value (\%) } & Women & $-15.4 \pm 3.1$ & $2.7 \pm 1.8$ & $-8.9 \pm 2.5$ & $3.4 \pm 1.3$ & $-16.3 \pm 3.3$ & $3.9 \pm 1.6$ & $-8.1 \pm 2.7$ & $3.0 \pm 2.0$ \\
\hline & & \multicolumn{8}{|c|}{ Theophylline Dosage (mg) } \\
\hline & & 400 & & & & 600 & & & \\
\hline \multirow[t]{2}{*}{ Serum Theophylline } & Men & $6.2 \pm 0.4 \dagger$ & & & & $8.5 \pm 0.4 \dagger$ & & & \\
\hline & Women & $9.8 \pm 0.6^{\mathrm{a}}$ & & & & $11.6 \pm 0.7^{\mathrm{a}}$ & & & \\
\hline $\begin{array}{l}\text { Olfactometry (see ref } \\
22 \text { ) }\end{array}$ & & PYRD & $\mathrm{NO}_{2} \mathrm{~B}$ & THIO & AA & PYRD & $\mathrm{NO}_{2} \mathrm{~B}$ & THIO & AA \\
\hline Detection & Men & $8.8 \pm 0.5$ & $9.2 \pm 0.6$ & $8.5 \pm 0.7$ & $8.9 \pm 0.7$ & $8.3 \pm 0.3$ & $9.3 \pm 0.4$ & $8.6 \pm 0.5$ & $9.9 \pm 0.4$ \\
\hline Threshold (in BU) & Women & $7.8 \pm 0.4^{\mathrm{dl}}$ & $8.4 \pm 0.7^{\mathrm{el}}$ & $8.1 \pm 0.7$ & $9.1 \pm 0.6$ & $8.0 \pm 0.5^{\mathrm{el}}$ & $8.6 \pm 0.6^{\mathrm{dl}}$ & $7.8 \pm 0.6^{\mathrm{dl}}$ & $8.6 \pm 0.6^{\mathrm{el}}$ \\
\hline Recognition & Men & $9.9 \pm 0.8$ & $10.5 \pm 0.4$ & $10.3 \pm 0.5$ & $9.8 \pm 0.7$ & $10.6 \pm 0.3$ & $10.3 \pm 0.4$ & $10.4 \pm 0.3$ & $10.8 \pm 0.3$ \\
\hline Threshold (in BU) & Women & $9.5 \pm 0.4^{\mathrm{dl}}$ & $10.1 \pm 0.5^{\mathrm{e} I}$ & $9.6 \pm 0.6^{\mathrm{cl}}$ & $10.5 \pm 0.5$ & $9.7 \pm 0.4$ & $9.9 \pm 0.5^{\mathrm{dl}}$ & $9.8 \pm 0.5^{\mathrm{el}}$ & $10.0 \pm 0.5^{\mathrm{el}}$ \\
\hline Magnitude & Men & $15.2 \pm 3.9$ & $10.8 \pm 4.1$ & $13.6 \pm 5.0$ & $13.1 \pm 4.3$ & $16.0 \pm 3.4$ & $10.4 \pm 2.7$ & $12.6 \pm 2.9$ & $7.8 \pm 2.2$ \\
\hline Estimation (\%) & Women & $24.9 \pm 5.0$ & $14.2 \pm 5.2$ & $15.8 \pm 4.2$ & $7.1 \pm 2.9$ & $24.2 \pm 4.1$ & $13.9 \pm 3.4$ & $15.7 \pm 3.7$ & $10.2 \pm 3.0$ \\
\hline Hedonic & Men & $-11.8 \pm 3.5$ & $-2.6 \pm 3.4$ & $-9.3 \pm 5.1$ & $6.0 \pm 4.3$ & $-10.5 \pm 2.8$ & $6.8 \pm 2.2$ & $-8.4 \pm 2.8$ & $4.9 \pm 2.0$ \\
\hline Value (\%) & Women & $-\mid 5.7 \pm 5.3$ & II. $2 \pm 5.5$ & $-9.7 \pm 3.6$ & $0.7 \pm 1.9$ & $-17.9 \pm 4.7$ & $4.8 \pm 3.4$ & $-10.6 \pm 3.4$ & $4.7 \pm 2.1$ \\
\hline
\end{tabular}

*Mean \pm SEM

†Serum theophylline level (in $\mathrm{mg} / \mathrm{L}$ )

PYRD, pyridine, $\mathrm{NO}_{2} \mathrm{~B}$, nitrobenzene

THIO, thiophene, AA, amyl acetate

$\mathrm{BU}$, bottle unites (see ref 22)

On $200 \mathrm{mg}$ theophylline there were no significant gender differences in olfactometry; however, DTs and RTs for both men and women for all odors decreased (more sensitive) and changes in women, while not significantly different from those in men, were lower (more sensitive) than in men for DTs of nitrobenzene and thiophene and RT for amyl acetate. RT for pyridine among men was significantly decreased (more sensitive) than before treatment. MEs for all odors among both men and women increased (more intense) than before treatment but there were no significant gender differences. Hs for unpleasant odors of pyridine and thiophene increased among men and for pyridine among women (judged as more unpleasant) but there were no significant gender differences.
With respect to men

${ }^{\mathrm{a}} \mathrm{p}<0.001$

${ }^{\mathrm{e}} \mathrm{p}<0.05$
With respect to pre treatment

$$
\begin{aligned}
& { }^{c l} p<0.0 \text { I } \\
& { }^{d l} p<0.025 \\
& { }^{\text {el }} p<0.05
\end{aligned}
$$

On 400mg theophylline there were also no significant gender differences in olfactometry but there were trends of differences. DTs for all odors and RTs for all odors except amyl acetate were lower (more sensitive) in women than in men. DTs for pyridine and nitrobenzene and RTs for pyridine, nitrobenzene and thiophene among women were significantly decreased (more sensitive) than before treatment but not significantly decreased among men [although all but DT for pyridine were decreased (more sensitive) than before treatment]. ME for three odors (pyridine, nitrobenzene and thiophene) were judged consistently higher (more intense) by women than by men and Hs for unpleasant odors of pyridine and thiophene were judged more unpleasant by women than men. 
On 600mg theophylline there were also no significant gender differences in olfactometry but trends of differences previously observed continued and increased. DTs for all odors were decreased (more sensitive) in women compared to men as were RTs for nitrobenzene, thiophene and amyl acetate; these differences were statistically significantly decreased (more sensitive) from pretreatment values (except for DTs for pyridine) whereas all DTs and RTs for men were decreased (more sensitive) from pretreatment values but not statistically significantly different. On this theophylline dose MEs for each odor were consistently higher (more intense) in women than in men and Hs for the unpleasant odors of pyridine and thiophene were judged more unpleasant by women than men.

To analyze these data in a systematic manner results of all 16 olfactometry measurements were combined (4 DTs, 4RTs, 4MEs and 4Hs values) and overall differences in smell function with respect to gender were compared (Table 3 ). These differences are illustrated with respect to total number of gender differences in DTs, RTs, MEs and $\mathrm{Hs}$ as measured in Table 2 and illustrated in Table 3; for example, in the untreated state all four DTs in men were below (more sensitive) those in women, one RT of four in men was below (more sensitive) that in women, ME for two of four odors in men were higher (more sensitive) than in women and $\mathrm{Hs}$ for one of two pleasant odors (nitrobenzene) in men were higher (more pleasant) than in women so that olfactory sensitivity in eight of 16 measurements were more sensitive (or more pleasant) in men than in women whereas eight of 16 measurements were more sensitive (or more pleasant) in women than in men. As the oral theophylline dose increased there was a consistent relative increase in sensitivity in women compared to men. For these 16 variables as theophylline dose increased from 200 to $600 \mathrm{mg}$ women demonstrated consistently increased sensitivity in olfactory measurements than did men (10 of 16 better on $200 \mathrm{mg}, 12$ of 16 better on $400 \mathrm{mg}$ and 14 of 16 better on $600 \mathrm{mg}$ ). On $600 \mathrm{mg}$ of theophylline, using both $\mathrm{X}^{2}$ and the sign test, significantly increased olfactory sensitivity was present in women compared to men.

Table 3 Gender differences in olfactometry in men and women after theophylline treatment

\begin{tabular}{llll}
\hline $\begin{array}{l}\text { Theophylline } \\
\text { dosage }(\mathbf{m g})\end{array}$ & $\begin{array}{l}\text { Men more } \\
\text { sensitive }\end{array}$ & $\begin{array}{l}\text { Women more } \\
\text { sensitive }\end{array}$ & $\mathbf{X}^{2}$ \\
\hline No Treatment & $8 / 16$ & $8 / 16$ & NS \\
200 & $6 / 16$ & $10 / 16$ & NS \\
400 & $4 / 16$ & $12 / 16$ & NS \\
600 & $2 / 16$ & $14 / 16$ & $p<0.05$
\end{tabular}

Numerator,Total number of smell function tests in which sensitivity differences occurred between men and women based on olfactometry.

Denominator, Total smell function tests performed.

NS, not significant

Mean serum theophylline levels at termination of each treatment period were consistently higher in women than men with differences statistically significant at each theophylline dose (Tables 1), (Table 2). On $200 \mathrm{mg}$ theophylline levels in women were $31 \%$ higher, on $400 \mathrm{mg}$ $58 \%$ higher and on $600 \mathrm{mg} 36 \%$ higher (Table2).

Serum theophylline relative to body mass in men and women are shown in Table 4. At each theophylline dose serum theophylline per kg body mass increased and were consistently higher in women compared to men varying from 1.5-1.9times higher. Results of the ANOVA (not shown) confirm these results.
Table 4 Serum theophylline per kg body mass in men and women

\begin{tabular}{llll}
\hline \multicolumn{4}{l}{ Theophylline dosage [mg] } \\
\hline & 200 & 400 & 600 \\
\hline Men (134) & $0.086^{*}$ & 0.015 & 0.021 \\
Women (178) & 0.013 & 0.029 & 0.035 \\
\hline
\end{tabular}

*Ratio of mean serum theophylline (in $\mathrm{mg} / \mathrm{L}$ )/mean body mass (in $\mathrm{kg}$ )

\section{( )Number of Patients}

Comparison of serum theophylline in men and women at each theophylline dose categorized by clinical etiology (Table 5) illustrates those differences in theophylline levels were not uniformly distributed across all etiologies. On 200mg, while drug levels in women were consistently higher than in men, levels were statistically significantly higher only with respect to the total gender group. On 400mg levels in women were also consistently higher than in men, but statistically significantly higher only with respect to the total gender group and in patients with allergic rhinitis and idiopathic hyposmia. On $600 \mathrm{mg}$ levels in women were again consistently higher than in men, statistically significantly higher overall but statistically significantly higher only in patients with allergic rhinitis and other pathologies. As treatment dose of oral theophylline increased differences in serum theophylline increased in a stepwise manner as previously demonstrated (Table 2) but most consistently in patients with allergic rhinitis. The clinical characteristics which might enhance serum theophylline in these latter patients are unclear.

Table 5 Differences in serum theophylline between hyposmic men and women by hyposmia etiology

\begin{tabular}{|c|c|c|c|c|}
\hline \multirow{2}{*}{ Patient Diagnosis } & & \multicolumn{3}{|c|}{ Theophylline Dosage [mg] } \\
\hline & & 200 & 400 & 600 \\
\hline \multirow[t]{2}{*}{ All Patients } & Men (I34) & $3.5 \pm 0.2 * \dagger$ & $6.2 \pm 0.4$ & $8.5 \pm 0.4$ \\
\hline & Women (I78) & $4.4 \pm 0.3^{e}$ & $9.8 \pm 0.6^{a}$ & $11.6 \pm 0.7^{a}$ \\
\hline \multirow[t]{2}{*}{ Allergic Rhinitis } & Men (52) & $3.4 \pm 0.4$ & $5.7 \pm 0.5 \dagger$ & $7.7 \pm 0.5 \dagger$ \\
\hline & Women (45) & $4.1 \pm 0.4$ & $8.4 \pm 1.0^{d}$ & $12.5 \pm 1.1^{\mathrm{a}}$ \\
\hline \multirow{2}{*}{$\begin{array}{l}\text { Congenital } \\
\text { Hyposmia }\end{array}$} & Men (7) & $2.4 \pm 1.0$ & $6.3 \pm 3.0$ & $8.4 \pm 1.4$ \\
\hline & Woman (16) & $4.1 \pm 0.7$ & $12.9 \pm 3.6$ & $9.8 \pm 2.3$ \\
\hline \multirow[t]{2}{*}{ Head Injury } & Men (I8) & $2.8 \pm 0.7$ & $4.5 \pm 1.5$ & $7.0 \pm 1.1$ \\
\hline & Women (25) & $4.0 \pm 0.5$ & $6.8 \pm 1.2$ & $10.1 \pm 1.2$ \\
\hline \multirow[t]{2}{*}{$\begin{array}{l}\text { Idiopathic } \\
\text { Hyposmia }\end{array}$} & Men (I8) & $5.2 \pm 0.4$ & $7.2 \pm 1.5$ & $10.0 \pm 1.2$ \\
\hline & Women (I0) & $5.4 \pm 1.8$ & $\mid 4.8 \pm 1.4^{b}$ & $13.1 \pm 2.6$ \\
\hline \multirow{2}{*}{$\begin{array}{l}\text { Post Influenza- } \\
\text { Like Hyposmia }\end{array}$} & Men (36) & $4.0 \pm 0.4$ & $7.4 \pm 0.6$ & $7.8 \pm 0.8$ \\
\hline & Women (6I) & $4.2 \pm 0.2$ & $8.2 \pm 0.8$ & $8.7 \pm 0.7$ \\
\hline \multirow[t]{2}{*}{ Other Pathology } & Men (3) & $3.2 \pm 1.2$ & $6.2 \pm 2.4$ & $7.9 \pm 1.1$ \\
\hline & Women (I7) & $4.5 \pm 0.8$ & $9.3 \pm 1.4$ & $12.9 \pm 1.5$ \\
\hline
\end{tabular}

\section{*Mean \pm SEM}

\section{( )Number of Patients}

†Serum theophylline (in $\mathrm{mg} / \mathrm{L}$ )

With respect to men

${ }^{\mathrm{a}} \mathrm{P}<0.00$ I

${ }^{\mathrm{b}} \mathrm{P}<0.005$

${ }^{\mathrm{d}} \mathrm{P}<0.025$

${ }^{\text {e }} \mathrm{p}<0.05$ 
Evaluation of serum theophylline per kg body mass with respect to hyposmia etiology (Table 6) demonstrates results similar to those in Table 3. Overall, in the total group, the ratio of serum theophylline per $\mathrm{kg}$ body mass was significantly higher in women than in men indicating that body mass was a factor in determining higher theophylline levels in women compared to men. Ratios of serum theophylline per $\mathrm{kg}$ body mass increased at each theophylline dose with ratios in women consistently higher than in men. These ratios are lower in men with head injury at lower levels of theophylline than in all other patient categories consistent with their resistance to hyposmia correction at low doses of the drug. ${ }^{12,13}$

Table 6 Serum theophylline per kg body mass by hyposmia etiology in men and women

\begin{tabular}{|c|c|c|c|c|c|c|}
\hline \multirow[b]{3}{*}{ Patient diagnosis } & \multicolumn{6}{|c|}{ Theophylline dosage [mg] } \\
\hline & 200 & & 400 & & 600 & \\
\hline & Men & Women & Men & Women & Men & Women \\
\hline All Patients $(134, \mid 78)$ & $0.09 I \pm 0.00 I *$ & $0.015 \pm 0.002^{\mathrm{d}}$ & $0.015 \pm 0.002$ & $0.02850 .005^{d}$ & $0.022 \pm 0.001$ & $0.035 \pm 0.005^{c}$ \\
\hline Allergic Rhinitis $(52,45)$ & $0.073 * *$ & 0.011 & 0.014 & 0.023 & 0.018 & 0.038 \\
\hline Congenital Hyposmia $(7,16)$ & 0.081 & 0.015 & 0.014 & 0.034 & 0.023 & 0.040 \\
\hline Head Injury $(18,25)$ & 0.055 & 0.012 & 0.082 & 0.013 & 0.022 & 0.023 \\
\hline Idiopathic Hyposmia $(18,10)$ & 0.013 & 0.016 & 0.020 & 0.043 & 0.025 & 0.045 \\
\hline Post Influenza-Like Hyposmia $(36,61)$ & 0.011 & 0.014 & 0.017 & 0.029 & 0.023 & 0.032 \\
\hline
\end{tabular}

*Ratio of mean serum theophylline (in $\mathrm{mg} / \mathrm{L}$ )/mean body mass (in $\mathrm{kg}$ )

**Mean \pm SEM

( )Number of Patients (men, women)

Compared to men

${ }^{\mathrm{c}} \mathrm{p}<0.01$

${ }^{\mathrm{d}} \mathrm{P}<0.05$

Serum theophylline in pre or postmenopausal women (Table 7) demonstrate that while mean levels of the postmenopausal group are higher than those of the premenopausal group for each theophylline dose there were no significant differences between the groups suggesting that hormonal factors were not a major source of these differences. The range of results overlaps in each treatment group. Serum protein levels in men and women were also not significantly different (data not shown).

Table 7 Differences in serum theophylline related to premenopausal or postmenopausal status

\begin{tabular}{llll}
\hline \multicolumn{5}{l}{ Theophylline dosage [mg] } \\
\hline & 200 & 400 & 600 \\
\hline Premenopausal & $2.3 \pm 1.9 *+(1.7-5.7)$ & $\begin{array}{l}7.5 \pm 2.3(5.8- \\
22.1)\end{array}$ & $\begin{array}{l}10.6 \pm 1.3(5.8- \\
22.1)\end{array}$ \\
Postmenopausal & $4.0 \pm 0.4(2.8-8.3)$ & $\begin{array}{ll}11.2 \pm 1.7(5.4- \\
17.3)\end{array}$ & $\begin{array}{l}11.9 \pm 1.8(1.0- \\
18.0)\end{array}$
\end{tabular}

*Mean \pm SEM

†Serum theophylline (in $\mathrm{mg} / \mathrm{L}$ )

( )Range (in $\mathrm{mg} / \mathrm{L}$ )

\section{Discussion}

These studies demonstrate that hyposmic women exhibit increased subjective and olfactometry related sensitivity to odors than did hyposmic men relative to their oral theophylline treatment. Treatment with theophylline may be a factor which accentuates the increased olfactory sensitivity in women compared to men shown by the doseresponse relationship in changes in both olfactometry acuity and in theophylline serum level. While the mechanism for this difference is not immediately clear these data demonstrate that serum levels of theophylline in hyposmic women were consistently higher than in men. These higher levels may play a role in this increased smell sensitivity of women over men but the olfactory difference was statistically significant clinically only after the highest theophylline dose was administered.

As noted above there are many prior studies of olfactory function in men and women. Reports indicate that women score better than men on tests of odor detection and/or identification, ${ }^{1,2}$ women give higher intensity and unpleasant ratings than men for unpleasant odors, ${ }^{3,4}$ women identify common odors better than men, ${ }^{5}$ exhibit better olfactory "functioning" than $\operatorname{men}^{10}$ and exhibit greater olfactory sensitivity than men. ${ }^{7,10}$ These differences were attributed to increased brain activation as measured by fMRI, ${ }^{1}$ to differences in specific activation sites in the hypothalamus ${ }^{22}$ or to differences in elementary encoding of odorous signals. ${ }^{8}$ A more recent study has reported that women have up to $50 \%$ more olfactory bulb cells than do men using a technique termed isotropic fractionation. ${ }^{23}$

However, other studies have reported no significant gender differences on behavioral olfactory tests between men and women ${ }^{6-9}$ or between adolescent or young boys or girls. ${ }^{24}$ However, normal women exhibit increased daily circadian olfactory and gustatory variation than do men. ${ }^{25}$ Over the menstrual cycle women exhibit increased olfactory acuity at ovulation and return to baseline activity at menses. ${ }^{26}$ These differences were small and measurable only under carefully controlled conditions with repeated studies as in the present study. Significant differences in smell function between hyposmic men and women were not apparent as they presented before treatment in our clinical program. ${ }^{13,14}$ Comparison of smell function in pre or postmenopausal hyposmic women before any treatment also revealed 
no significant differences ${ }^{13,14}$ and in the present study theophylline levels in pre and postmenopausal women at the various dose levels of theophylline also did not demonstrate significant differences.

Gender drug variations have been previously related to differences in body mass, blood volume, gastric emptying time, serum protein levels, hormonal state, age, cytochrome p450 activity, drug transporter function differences, drug excretion differences and other gender related factors. ${ }^{27-29}$ In the present studies differences in serum theophylline between men and women may be dependent upon body mass differences but independent of serum protein levels or hormonal status of the women patients.

Theophylline has been used to treat patients with asthma for many years..$^{30}$ Although its use has decreased due to introduction of other effective therapies its pharmacokinetics ${ }^{31,32}$ and pharmacodynamics ${ }^{33}$ have been well studied as have general physiological responses to methylxanthenes. ${ }^{34}$ Gender differences in drug therapy are well known ${ }^{35}$ and gender ${ }^{36}$ and age ${ }^{37}$ differences in relationship to theophylline treatment have been previously reported.

Differences we observed in serum theophylline between hyposmic men and women have not been previously reported and mechanisms underlying these differences are not readily apparent. Although theophylline ${ }^{38}$ and phosphodiesterase inhibitors of various types have been given to patients with a variety of clinical conditions, ${ }^{36-38}$ gender differences in theophylline treatment, although previously reported for pharmacokinetic differences, ${ }^{36}$ have not been reported for differences in sensory function.

There are several limitations to this study. The basis for differences we observed is complex. Body mass differences in relationship to theophylline metabolism between men and women may be a factor. Gender differences in drug pharmacokinetics and pharmacodynamics are well known based upon drug bioavailability, distribution, metabolism and elimination, ${ }^{27,28}$ Some gender differences in metabolic clearance rate of theophylline have been reported. ${ }^{39}$ A lower cAMP response to isoproterenol was reported in female asthmatics ${ }^{40}$ and theophylline decreased blood eosinophils and decreased estrogeninduced uterine eosinophilia. ${ }^{41}$ These and other influences may have played some role in the increased olfactory sensitivity we observed in women when taking theophylline.

\section{Conclusion}

Hyposmic women treated with oral theophylline exhibit increased olfactory function than do men. This difference may relate to the manner in which women metabolize theophylline different from men. Further investigation of gender differences to oral theophylline treatment may offer an opportunity to learn more about olfactory responses to this drug and the relatively more significant action that this drug may play in women than in men.

\section{Acknowledgements}

None.

\section{Conflict of interest}

The author declares no conflict of interest

\section{References}

1. Yousem DM, Maldjian JA, Siddiqi F, et al. Gender effects on odorstimulated functional magnetic resonance imaging. Brain Res. 1999;818(2):480-487.
2. Lehrner JP. Gender differences in long-term odor recognition memory: verbal versus sensory influences and the consistency of label use. Chem Senses. 1993;18(1):17-26.

3. Olofsson JK, Nordin S. Gender differences in chemosensory perception and event-related potentials. Chem Senses. 2004;29(7):629-637.

4. Ernstgård L, Gullstrand E, Löf A, et al. Are women more sensitive than men to 2-propanol and m-xylene vapours? Occup Environ Med. 2002;59(11):759-767.

5. Cain WS. Odor identification by males and females: predictions vs performance. Chem Senses. 1982;7(2):129-142.

6. Evans WJ, Cui L, Starr A. Olfactory event-related potentials in normal human subjects: effects of age and gender. Electroencephalogr Clin Neurophysiol. 1995;95(4):293-301.

7. Dalton P, Doolittle N, Breslin PA. Gender-specific induction of enhanced sensitivity to odors. Nat Neuro sci. 2002;5(3):199-200.

8. Bengtsson S, Berglund H, Gulyas B, et al. Brain activation during odor perception in males and females. Neuroreport. 2001;12(9):2027-2033.

9. Venstrom D, Amoore J. Olfactory threshold, in relation to age, sex or smoking. J Food Sci. 1968;33(3):264-265.

10. Öberg C, Larsson M, Bäckman L. Differential sex effects in olfactory functioning: the role of verbal processing. J Int Neuropsychol Soc. 2002;8(5):691-698.

11. Barber CE. Olfactory acuity as a function of age and gender: a comparison of African and American samples. Int J Aging Hum Dev. 1997;44(4):317-334.

12. Henkin RI. Evaluation and treatment of human olfactory dysfunction. In: English GM, editor. Otolaryngology. Vol 2. Philadelphia: Lippincott; 1993. p. 1-86.

13. Henkin RI, Velicu I, Schmidt L. An open label controlled trial of theophylline for treatment of patients with hyposmia. Am J Med Sci. 2009;337(6):396-406.

14. Henkin RI, Levy LM, Fordyce A. Taste and smell function in chronic disease: a review of clinical and biochemical evaluation of taste and smell dysfunction in over 5000 patients at the taste and smell clinic in Washington, DC. Am J Otolaryngol. 2013;34(5):477-489.

15. Levy LM, Henkin RI, Hutter A, et al. Increased brain activation in response to odors in patients with hyposmia after theophylline treatment demonstrated by fMRI. J Comput Assist Tomogr. 1998;22(5):760-770.

16. Church JA, Bauer H, Bellanti JA, et al. Hyposmia associated with atopy. Ann Allergy. 1978;40(2):105-109.

17. Henkin RI, Levy LM. fMRI of congenital hyposmia: brain activation of odors and imagination of odors and tastes. J Comput Assist Tomogr. 2002;26(1):39-61.

18. Schechter PJ, Henkin RI. Abnormalities of taste and smell following head trauma. J Neurol Neurosurg Psychiat.1974;37(7):802-810.

19. Henkin RI, Larson AL, Powell RD. Hypogeusia, dysgeusia, hyposmia and dysosmia following influenza-like infection. Ann Otol Rhin Laryngol. 1975;84(5 pt 1):672-682.

20. Henkin RI, Schecter PJ, Friedewald WT, et al. A double blind study of the effects of zinc sulfate on taste and smell dysfunction. Am J Med Sci. 1976;272(3):285-299.

21. Jolley ME, Stroupe SD, Schwenzer KS, et al. Fluorescence polarization immunoassay. iii. an automated system for therapeutic drug determination. Clin Chem. 1981;27(9):1575-1579.

22. Savic I, Berglund H, Gulyas B, et al. Smelling of odorous sex hormonelike compounds causes sex-differentiated hypothalamic activations in 
humans. Neuron. 2001;31(4):661-668.

23. Oliveira-Pinto AV, Santos RM, Coutinho RA, et al. Sexual dimorphism in the human olfactory bulb: females have more neurons and glial cells than males. PLoS ONE. 2014;9(11):e111733.

24. Koelega HS, Köster EP. Some experiments on sex differences in odor perception. Ann NY Acad Sci. 1974;237(0):234-246.

25. Henkin RI. A study of circadian variation in taste and smell in normal man and in patients with adrenal cortical insufficiency: the role of adrenal cortical steroids. In: Ferrin M, et al. editors. Biorhythms and Human Reproduction. New York: Wiley; 1974;397-408.

26. Henkin RI. Sensory changes during the menstrual cycle. In: Ferrin M, et al. editors. Biorhthyms and Human Reproduction. New York: Wiley; 1974. p. 227-285.

27. Tanaka E. Gender-related differences in pharmacokinetics and their clinical significance. J Clin Pharm Ther. 1999;24(5):339-346.

28. Gandhi M, Aweeka F, Greenblatt RM, et al. Sex differences in pharmacokinetics and pharmacodynamics. Annu Rev Pharmacol Toxicicol. 2004;44:499-523.

29. Schwartz JB. The influence of sex on pharmacokinetics. Clin Pharmacokinet. 2003;42(2):107-121.

30. Weinberger M. Theophylline for treatment of asthma. J Pediatr. 1978;92(1):1-7.

31. Coleman RW, Hedberg RL. Comparison of three methods for estimating theophylline pharmacokinetics. Clin Pharm. 1983;2(2):148-152.

32. Hendeles L, Weinberger M. Theophylline. A "state of the art" review. Pharmacotherapy. 1983;3(1):2-44.
33. Peck CC, Nichols AI, Baker J, et al. Clinical pharmacodynamics of theophylline. J Allergy Clin Immunol. 1985;76(2 pt 2):292-297.

34. Yesair DW, Branfman AR, Callahan MM. Human disposition and some biochemical aspects of methylxanthines. Prog Clin Biol Res. 1984;158:215-233.

35. Franconi F, Brunelleschi S, Steardo L, et al. Gender differences in drug responses. Pharmacol Res. 2007;55(2):81-95.

36. Jennings TS, Nafziger AN, Davidson L, et al. Gender differences in hepatic induction and inhibition of theophylline pharmacokinetics and metabolism. J Lab Clin Med. 1993;122(2):208-216.

37. Shin SG, Juan D, Rammohan M. Theophylline pharmacokinetics in normal elderly subjects. Clin Pharmacol Ther. 1988;44(5):522-530.

38. Reffelmann T, Kloner RA. Therapeutic potential of phosphodiesterase 5 inhibition for cardiovascular disease. Circulation. 2003;108(2):239-244.

39. Munakata M, Yamamoto H, Akiyama Y, et al. Female asthmatics have increased hypercapnic chemosensitivity during the luteal phase which is not associated with decline in airway function. Chest. 1993;104(6):17181722 .

40. Tan KS, McFarlane LC, Lipworth BJ. Paradoxical down-regulation and desensitization of $\beta 2$-adrenoceptors by exogenous progesterone in female asthmatics. Chest. 1997;111(4):847-851.

41. Steinsapir J, Rojas AM, Tchernitchin A. Theophylline-estrogen interaction in the rat uterus: role of the ovary. Am J Physiol Endocrinol Metab. 1982;242(2):E121-126. 